\title{
Nociceptor Sensitization by Extracellular Signal-Regulated Kinases
}

\author{
K. O. Aley, ${ }^{1}$ Annick Martin, ${ }^{2}$ Thomas McMahon, ${ }^{2}$ Janine Mok, ${ }^{1}$ Jon D. Levine, ${ }^{1}$ and Robert O. Messing ${ }^{2}$ \\ ${ }^{1}$ Departments of Medicine and Oral Surgery, National Institutes of Health Pain Center at the University of California, San \\ Francisco, San Francisco, California 94143, and the 2Department of Neurology, Ernest Gallo Clinic and Research Center \\ at the University of California, San Francisco, Emeryville, California 94608
}

Inflammatory pain, characterized by a decrease in mechanical nociceptive threshold (hyperalgesia), arises through actions of inflammatory mediators, many of which sensitize primary afferent nociceptors via G-protein-coupled receptors. Two signaling pathways, one involving protein kinase A (PKA) and one involving the epsilon isozyme of protein kinase $\mathrm{C}(\mathrm{PKC} \epsilon)$, have been implicated in primary afferent nociceptor sensitization. Here we describe a third, independent pathway that involves activation of extracellular signal-regulated kinases (ERKs) 1 and 2. Epinephrine, which induces hyperalgesia by direct action at $\beta_{2}-$ adrenergic receptors on primary afferent nociceptors, stimulated phosphorylation of ERK1/2 in cultured rat dorsal root ganglion cells. This was inhibited by a $\beta_{2}$-adrenergic receptor blocker and by an inhibitor of mitogen and extracellular signalregulated kinase kinase (MEK), which phosphorylates and activates $\mathrm{ERK} 1 / 2$. Inhibitors of $\mathrm{G}_{\mathrm{i} / \mathrm{o}}$-proteins, Ras farnesyltrans- ferases, and MEK decreased epinephrine-induced hyperalgesia. In a similar manner, phosphorylation of ERK1/2 was also decreased by these inhibitors. Local injection of dominant active MEK produced hyperalgesia that was unaffected by PKA or PKC $\epsilon$ inhibitors. Conversely, hyperalgesia produced by agents that activate PKA or PKC $\epsilon$ was unaffected by MEK inhibitors. We conclude that a Ras-MEK-ERK1/2 cascade acts independent of PKA or PKC $\epsilon$ as a novel signaling pathway for the production of inflammatory pain. This pathway may present a target for a new class of analgesic agents.

Key words: extracellular signal-regulated kinase; mitogenactivated protein kinase; protein kinase $C \epsilon$; protein kinase $A$; epinephrine; pain; hyperalgesia; nociceptor; Ras; $\beta$-adrenergic receptor; mitogen and extracellular signal-regulated kinase kinase; G-protein
Current evidence indicates that at least two signaling pathways mediate hyperalgesia produced by inflammatory agents. The inflammatory mediators prostaglandin $\mathrm{E}_{2}\left(\mathrm{PGE}_{2}\right)$, serotonin, and adenosine produce hyperalgesia through activation of protein kinase A (PKA) (Gold et al., 1996, 1998; Khasar et al., 1998a, 1999a), and this process is facilitated by nitric oxide (Aley et al., 1998; Chen and Levine, 1999). On the other hand, epinephrine, acting through $\beta_{2}$-adrenergic receptors on primary afferent nociceptors, produces mechanical hyperalgesia in part through PKA but also through the epsilon isozyme of protein kinase $\mathrm{C}$ (PKC $\epsilon$ ) (Khasar et al., 1999a). PKC $\epsilon$ also contributes to bradykinininduced sensitization of nociceptors to heat (Cesare et al., 1999).

PKA and PKC $\epsilon$ mediate nociceptor sensitization by modulating the activity of a tetrodotoxin-resistant sodium current that is sensitized by direct-acting hyperalgesic agents (Gold et al., 1996; Khasar et al., 1999a,b). We originally thought that PKA and PKC $\epsilon$ signaling pathways might converge at extracellular signalregulated kinases 1 and 2 (ERK1/2), because ERK1/2 are modulated by PKA and PKC $\epsilon$ (Hundle et al., 1995; Vossler et al., 1997; Grewal et al., 2000). Moreover, $\beta_{2}$-adrenergic receptors, like several other G-protein-coupled receptors, can activate ERKs (Daaka et al., 1997; Della Rocca et al., 1997; Wan and Huang, 1998; Maudsley et al., 2000; Schmitt and Stork, 2000).

\footnotetext{
Received April 6, 2001; revised June 11, 2001; accepted June 15, 2001.

This work was supported by Public Health Service Grants NS21647 (J.D.L.) and AA10036 (R.O.M.).

K.O.A. and A.M. contributed equally to this work.

Correspondence should be addressed to Dr. Robert O. Messing, Ernest Gallo Clinic and Research Center at the University of California, San Francisco, 5858 Horton Street, Suite 200, Emeryville, CA 94608. E-mail: romes@itsa.ucsf.edu. Copyright (C) 2001 Society for Neuroscience 0270-6474/01/216933-07\$15.00/0
}

ERKs are mitogen-activated protein (MAP) kinases that mediate several cellular responses to mitogenic and differentiation signals (Lewis et al., 1998). They are activated by diverse extracellular stimuli, including several hormones and growth factors that activate G-protein-coupled receptors or receptor tyrosine kinases, leading to stimulation of Raf kinases, which phosphorylate and activate mitogen and extracellular signal-regulated kinase kinase (MEK). Activated MEK in turn phosphorylates and activates ERK1/2. PKA and cAMP can promote ERK activation via a Rap1-dependent pathway in neural cells, such as PC12 cells, that use B-Raf as the major Raf isoform (Ohtsuka et al., 1996; Vossler et al., 1997; Kawasaki et al., 1998; York et al., 1998; Grewal et al., 2000). In PC12 cells, PKC $\epsilon$ promotes ERK phosphorylation and activation by nerve growth factor (NGF) or epidermal growth factor (EGF) through an unknown mechanism (Hundle et al., 1995, 1997; Brodie et al., 1999). Thus, activation of ERKs in nociceptors could provide an important mechanism for convergence of PKA and PKC $\epsilon$ signaling pathways.

In this paper, we examined whether ERK activation is involved in pain signaling by examining epinephrine-treated rat dorsal root ganglion (DRG) neurons in culture and epinephrine-induced mechanical hyperalgesia in rats. We report that epinephrine activates ERKs in cultured DRG neurons and that a heterotrimeric $\mathrm{G}_{\mathrm{i}}$ - or $\mathrm{G}_{\mathrm{o}}$-protein, Ras, and MEK contribute to epinephrineinduced hyperalgesia, independent of PKC $\epsilon$ or PKA.

\section{MATERIALS AND METHODS}

Materials. Epinephrine, the selective $\beta_{2}$-adrenergic receptor antagonist ICI 118,551, $\mathrm{PGE}_{2}$ pertussis toxin, epinephrine, and the isoprenylation inhibitor perillic acid were purchased from Sigma (St. Louis, MO). The general PKC inhibitor bisindoylmaleimideI (BIM), the PKA inhibitor 
H89, the MEK inhibitors U0126 and PD98059, mouse 2.5 S NGF, and the farensyltransferase inhibitor FTase I were from Calbiochem (La Jolla, CA). The Walsh inhibitor peptide (WIPTIDE) of PKA was purchased from Peninsula Laboratories (Belmont, CA). Anti-phosphop42/44 MAP kinase (Thr202/Tyr204) antibody against the MEKphosphorylated forms of ERK1/2 and anti-ERK1/2 antibody were purchased from New England Biolabs (Beverly, MA) or, where indicated, from Upstate Biotechnology (Lake Placid, NY). Dominant active and kinase inactive recombinant MEK1 were purchased from Upstate Biotechnology. A specific activator of PKC $\epsilon, \psi \in \mathrm{R} A C K$ (receptor for activated C kinase), was a gift from D. Mochly-Rosen (Stanford University, Stanford, CA). A specific inhibitor of PKC $\epsilon, \epsilon \mathrm{V} 1-2$, was synthesized by SynPep (Danville, CA).

Cell culture. Dorsal root ganglia were collected from male adult Sprague Dawley rats (200 gm) obtained from Simonsen (Gilroy, CA) or from PKC $\epsilon$ null and wild-type C57BL/6J $\times 129$ SvJae mice of the F2 generation (Khasar et al., 1999a). The cells were dissociated by treating ganglia with $0.125 \%$ collagenase $\mathrm{P}$ for $2 \mathrm{hr}$, followed by a trypsin solution (0.025\% trypsin and $0.025 \%$ EDTA in HBSS) for 15 min. Trypsin was inactivated by adding $100 \mu \mathrm{g} / \mathrm{ml}$ soybean trypsin inhibitor and $2.5 \mathrm{mg} / \mathrm{ml}$ $\mathrm{MgSO}_{4}$. The cells were centrifuged at $300 \times g$ for $5 \mathrm{~min}$ and resuspended in culture media containing minimal essential medium (MEM) supplemented with $10 \%$ heat-inactivated fetal calf serum, $1 \times$ MEM vitamins, and $1000 \mathrm{U} / \mathrm{ml}$ each of penicillin and streptomycin. The culture was enriched for neurons by preplating on $100 \mathrm{~mm}$ culture dishes pretreated with $0.1 \mathrm{mg} / \mathrm{ml}$ poly-DL-ornithine in $15 \mathrm{~mm}$ sodium borate buffer. After culture for 15-20 hr, the loosely attached neuronal cells were collected and plated for $3 \mathrm{hr}$ on six-well plates coated with $0.1 \mathrm{mg} / \mathrm{ml}$ poly-DLornithine and $1 \mathrm{mg} / \mathrm{ml}$ laminin.

Western analysis. After drug treatment, cells from neuron-enriched DRG cultures were collected and centrifuged at $300 \times g$ for $5 \mathrm{~min}$ at $4{ }^{\circ} \mathrm{C}$. The pellets were resuspended in lysis buffer [50 mM Tris $\mathrm{HCl}, \mathrm{pH} 7.4,1 \%$ (v/v) NP-40, 0.25\% sodium deoxycholate, $150 \mathrm{~mm} \mathrm{NaCl}, 1$ mM EGTA, and $10 \mathrm{~mm}$ EDTA] and protease inhibitors (leupeptin and aprotinin at 40 $\mu \mathrm{g} / \mathrm{ml}$ each, $25 \mu \mathrm{g} / \mathrm{ml}$ soybean trypsin inhibitor, and $1 \mathrm{~mm}$ PMSF) and phosphatase inhibitors ( $25 \mathrm{~mm} \mathrm{NaF}, 1 \mathrm{~mm} \mathrm{Na} \mathrm{VO}_{4}, 40 \mathrm{~mm} \beta$ glycerophosphate, and $1 \mathrm{~mm}$ Na pyrophosphate). Proteins in $200 \mu \mathrm{g}$ samples of cell lysates were separated by SDS-PAGE using $12 \%$ polyacrylamide gels. The proteins were electroblotted onto Hybond $\mathrm{C}$ nitrocellulose membranes, which were incubated in a blocking solution containing $5 \%$ nonfat dry milk dissolved in PBS-T (137 mM NaCl, $2.7 \mathrm{~mm} \mathrm{KCl}, 1.47 \mathrm{~mm}$ $\mathrm{KH}_{2} \mathrm{PO}_{4}, 8 \mathrm{mM} \mathrm{NaHPO}_{4}, 0.5 \mathrm{mM} \mathrm{MgCl}_{2}$, and $0.9 \mathrm{mM} \mathrm{CaCl}_{2}, \mathrm{pH} 7.2$, and $0.1 \%$ Tween 20). Blots were incubated with anti-phospho-p42/44 MAP kinase antibody (diluted 1:500 in blocking buffer) overnight at $4^{\circ} \mathrm{C}$. Blots were rinsed three times in PBS-T and incubated in blocking buffer containing HRP-conjugated goat anti-rabbit IgG (diluted 1:1000; Boehringer Mannheim, Indianapolis, IN) for $1 \mathrm{hr}$ at $27^{\circ} \mathrm{C}$. Immunoreactive bands were visualized by enhanced chemiluminescence (Amersham Pharmacia Biotech, Piscataway, NJ). The membranes were then stripped of antibodies by incubation in $200 \mathrm{~mm} \mathrm{NaOH}$ for $20 \mathrm{~min}$ at $27^{\circ} \mathrm{C}$. After three washes in PBS-T, blots were incubated with anti-ERK1/2 antibody $(136 \mathrm{ng} / \mathrm{ml})$ for $1 \mathrm{hr}$ at $27^{\circ} \mathrm{C}$. After three washes in PBS-T, blots were incubated with HRP-conjugated goat anti-rabbit IgG (diluted 1:1000; Boehringer Mannheim) for $1 \mathrm{hr}$ at $27^{\circ} \mathrm{C}$, and immunoreactive bands were visualized by enhanced chemiluminescence and autoradiography. Immunoreactive bands on autoradiograms were analyzed by scanning densitometry using a flatbed scanner and NIH Image version 1.62 (W. Rasband, National Institutes of Health, Bethesda, MD). Data were normalized by dividing values obtained for phospho-ERK1 and phosphoERK2 immunoreactivity by the value obtained for total ERK1 immunoreactivity for each sample.

Immunofluorescence. Adult male Sprague Dawley rats were anesthetized with pentobarbital and transcardially perfused with PBS, followed by $4 \%$ paraformaldehyde (in PBS). DRGs were removed, post-fixed in $4 \%$ paraformaldehyde for $4 \mathrm{hr}$, treated with $30 \%$ sucrose (in PBS) for 24 $\mathrm{hr}$, and then embedded in Tissue-Tek OCT. Cryosections $(8 \mu \mathrm{m})$ were cut and stored at $-20^{\circ} \mathrm{C}$. Mounted DRG sections were allowed to thaw to room temperature. Sections were then incubated for $1 \mathrm{hr}$ in blocking solution (PBS containing 5\% normal donkey serum and $0.1 \%$ Triton $\mathrm{X}-100)$, overnight with anti-ERK1/2 (0.82 $\mu \mathrm{g} / \mathrm{ml}$; Upstate Biotechnology) and $1 \mathrm{hr}$ with FITC-conjugated donkey anti-rabbit $(7.5 \mu \mathrm{g} / \mathrm{ml}$; Jackson ImmunoResearch, West Grove, PA). Both primary and secondary antibodies were diluted in $1.5 \%$ normal donkey serum, in PBS.

Animal housing. For behavioral studies, male Sprague Dawley rats (200-250 gm; Bantin-Kingman, Fremont, CA) were individually housed and maintained under a $12 \mathrm{hr}$ light/dark cycle. The experimental rats were fed standard lab chow ad libitum. All experimental procedures were approved by the Institutional Animal Care and Use Committee of the University of California, San Francisco.

Mechanical nociceptive threshold. The nociceptive flexion reflex (Randall-Selitto paw-withdrawal test) was quantified with a Basile Analgesymeter (Stoelting, Chicago, IL), which applies a linearly increasing mechanical force to the dorsum of the rat's hindpaw. The mechanical nociceptive threshold was defined as the force in grams at which the rat withdrew its paw. On the day of the test, animals were brought to the laboratory and allowed to remain in the cage for $10-15 \mathrm{~min}$. They were allowed to crawl into individual cylindrical Perspex blocks and were lightly restrained there by closing both ends of the cylinder. The hindpaws of the rats were freed out of the cylinder through triangular slits on either side of the Perspex block, which allows easy access to the hindpaws during the test (Aley and Levine, 1999). The rats were allowed to acclimatize to the restrainer for 5-10 min, after which the hindpaws were exposed to the test stimulus. Three readings were taken at $5 \mathrm{~min}$ intervals, and their mean was considered the baseline threshold. After each drug administration, mechanical paw-withdrawal thresholds were determined again as the mean of three readings taken 20,25 , and $30 \mathrm{~min}$ after injection. The result was expressed as the percentage decrease in nociceptive threshold [(paw-withdrawal threshold after the drug - basal paw withdrawal threshold)/basal withdrawal threshold $\times 100]$.

Drugs for in vivo studies. Stock solutions $(1 \mu \mathrm{g} / \mu \mathrm{l}$ ) of BIM (in $10 \%$ dimethylsulfoxide) and $\epsilon \mathrm{V} 1-2$ and WIPTIDE (in $0.9 \%$ saline) were stored at $20^{\circ} \mathrm{C}$. Inhibitors were diluted with distilled water before intradermal injections into the paw using a $10 \mu \mathrm{l}$ microsyringe (Hamilton, Reno, NV). Injections of peptides $(1 \mu \mathrm{g} / 2.5 \mu \mathrm{l})$ were always preceded by injection of distilled water $(2.5 \mu \mathrm{l})$ to produce hypo-osmotic shock. This was done to increase cell membrane permeability to these agents (Tsapis and Kepes, 1977; West and Huang, 1980; Taiwo and Levine, 1989; Khasar et al., 1995; Widdicombe et al., 1996). The dose of each protein kinase inhibitor was separated from the distilled water by an air bubble $(<1 \mu \mathrm{l})$ so that the distilled water was injected into the paw first. Paw-withdrawal thresholds were measured again 10, 15, and 20 min after injecting the test agent. The mean of the paw-withdrawal thresholds obtained at these three times was then taken as the mechanical nociceptive threshold at the dose of the test agent used. The effect of each dose of a test agent was calculated as the percentage change from baseline.

Statistical analysis. The data are presented as mean $\pm \mathrm{SE}$ values and were compared using the one way ANOVA, followed by Newman-Keuls, Tukey's, or Dunnett's post hoc tests, as noted. Differences between means were considered significant at $p<0.05$.

\section{RESULTS}

Because of the recent evidence linking $\beta_{2}$-adrenergic receptor stimulation to activation of ERKs in non-neuronal cells (Daaka et al., 1997; Della Rocca et al., 1997; Wan and Huang, 1998; Maudsley et al., 2000; Schmitt and Stork, 2000), we examined whether ERK1/2 are present in rat DRG neurons and are activated by epinephrine. Immunofluorescence staining of isolated DRG demonstrated ERK1/2 immunoreactivity in cell bodies of DRG neurons (Fig. 1A). To measure responses to epinephrine, we next examined DRG neurons in culture. In unstimulated neurons, there was a basal level of phospho-ERK immunoreactivity (Fig. $1 B, C$ ). This was increased by $\sim 1$.7-fold after incubation with $1 \mu \mathrm{M}$ epinephrine. Epinephrine-evoked ERK phosphorylation was greatest after $5 \mathrm{~min}$ and gradually returned to basal levels after $60 \mathrm{~min}$. The effect of epinephrine was dose-dependent and appeared to be maximal at a concentration of $1 \mu \mathrm{M}$ (Fig. 1D). The maximal response to epinephrine was $\sim 30-50 \%$ of the response observed after incubation with a maximally effective concentration of NGF $(50 \mathrm{ng} / \mathrm{ml})$ for $5 \mathrm{~min}$ (Fig. $1 B)$.

Epinephrine-induced stimulation of ERK phosphorylation was mediated by $\beta_{2}$-adrenergic receptors and MEK because it was inhibited by ICI 118,551 (Samama et al., 1994) and by the selective MEK inhibitor U0126 (Favata et al., 1998) (Fig. 2A). ICI 118,551 , which is an inverse agonist, did not inhibit basal ERK phosphorylation, suggesting that basal activity of the $\beta_{2}$ receptor 
A

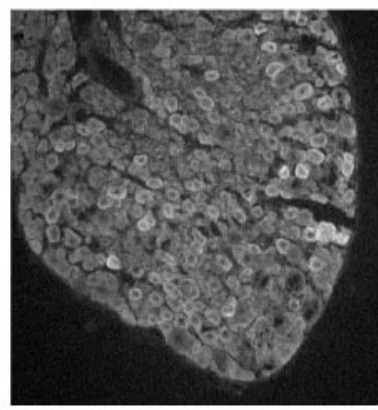

\section{ERK $1 / 2$}

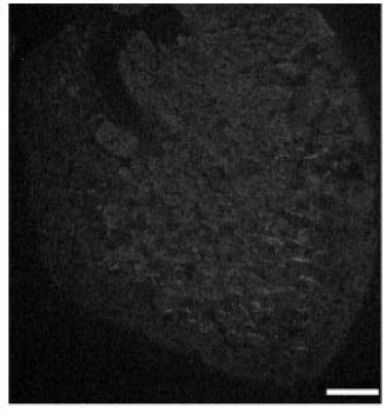

preabsorbed

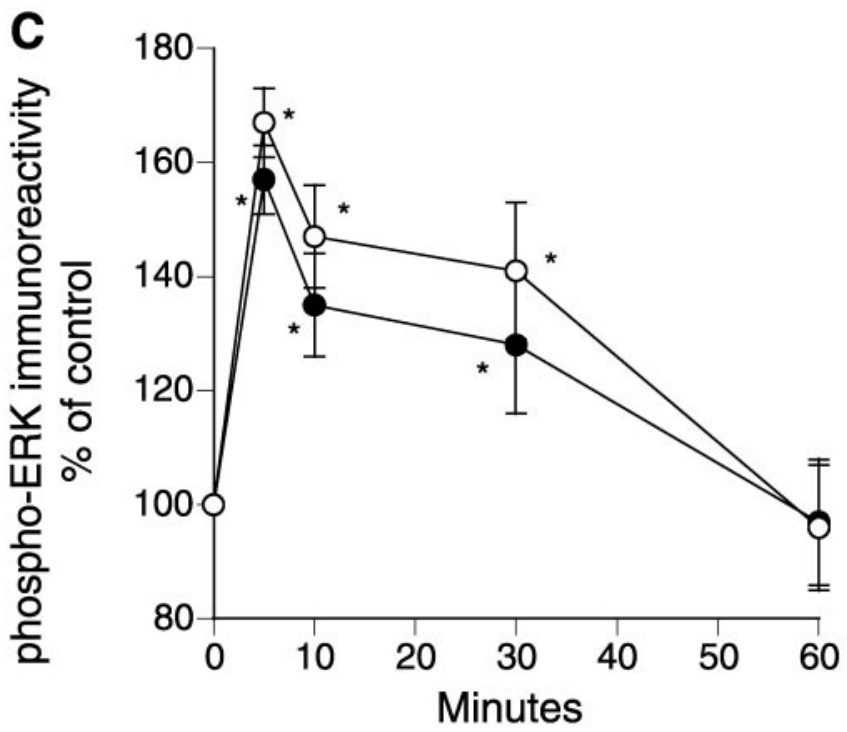

D

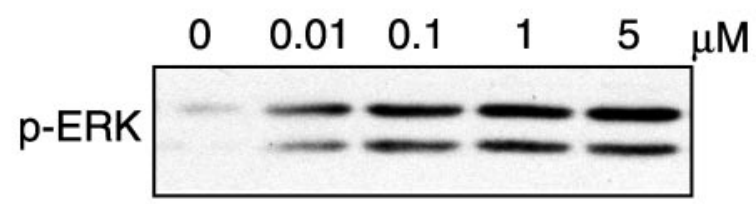

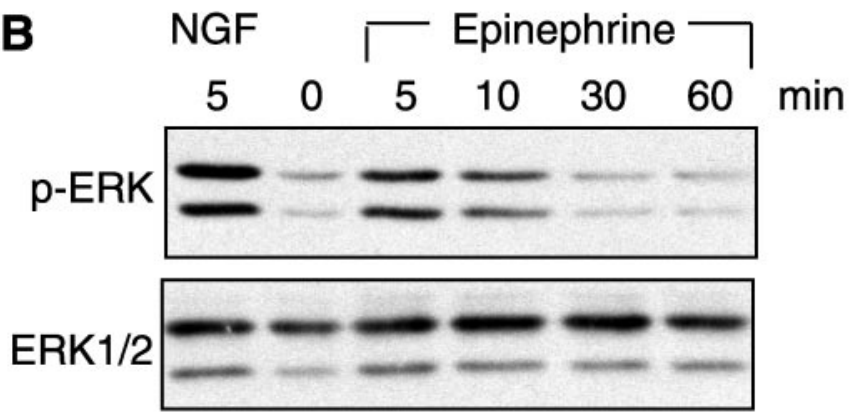

Figure 1. Epinephrine stimulates ERK1/2 phosphorylation in DRG neurons. $A$, ERK1/2 immunoreactivity present in cell bodies of neurons in freshly isolated DRG. The top shows incubation with anti-ERK1/2, whereas the bottom shows loss of immunoreactivity after preincubation of antibody with excess of peptide antigen. Scale bar, $100 \mu \mathrm{m} . B$, DRG cultures were treated with epinephrine for the indicated times and then processed for analysis of phospho-ERK1/2 immunoreactivity by Western analysis. Some cells were treated instead with $50 \mathrm{ng} / \mathrm{ml} \mathrm{NGF}$ for 5 min as a positive control. Blots were then stripped and probed with anti phospho-ERK1/2 antibody. Representative Western blot demonstrating NGF and epinephrine stimulation of ERK1/2 phosphorylation. $C$, Mean \pm SE values $(n=7-23)$ for phospho-ERK1/2 immunoreactivity normalized to total ERK1/2 immunoreactivity. ${ }^{*} p<0.05$ by ANOVA and Dunnett's multiple comparison test. $D$, Representative Western blot showing concentration dependence of epinephrine-induced ERK1/2 phosphorylation.

does not contribute significantly to the low level of phosphorylated ERK observed in unstimulated cultures.

Our previous studies indicated that signaling pathways involving PKA and PKC $\epsilon$ are important for primary afferent nociceptor sensitization induced by activation of $\beta_{2}$-adrenergic receptors (Khasar et al., 1999a,b). Therefore, we examined whether these kinases lie in a signaling pathway that includes MEK and ERK in DRG neurons. We found that treatment with H89, which inhibits PKA (Chijiwa et al., 1990), or calphostin C, which inhibits several PKC isozymes including PKC $\epsilon$ (Mayne and Murray, 1998), did not reduce epinephrine-stimulated ERK phosphorylation (Fig. $2 B$ ). Moreover, treatment with epinephrine evoked similar levels of ERK phosphorylation in mouse DRG cultures obtained from wild-type and PKC $\epsilon$ null mice (Fig. 2C). These findings indicate that epinephrine stimulates ERK phosphorylation in DRG neurons through a signaling pathway that does not involve PKA or PKC $\epsilon$.

We next evaluated whether MEK contributes to epinephrineinduced hyperalgesia and whether this is independent of PKA or PKC $\epsilon$. Intradermal injection of epinephrine decreased mechani- cal nociceptive thresholds by $\sim 35 \%$, and this effect was inhibited by the MEK inhibitors U0126 and PD98059 (Favata et al., 1998) (Fig. 3A). However, U0126 and PD98059 had no effect on hyperalgesia induced by $\mathrm{PGE}_{2}$, which requires PKA activation for its pronociceptive effect (Aley and Levine, 1999; Chen and Levine, 1999), or by $\psi \epsilon \mathrm{RACK}$, a specific activator of PKC $\epsilon$ (Dorn et al., 1999; Aley et al., 2000). Treatment with a dominant active MEK mutant was sufficient to induce hyperalgesia (Fig. 2D). This effect required the kinase activity of MEK because a kinase-dead MEK mutant was ineffective. Treatment with the specific PKC $\epsilon$ inhibitor $\epsilon$ V1-2 (Johnson et al., 1996; Khasar et al., 1999a) or with the PKA inhibitor WIPTIDE did not reduce hyperalgesia induced by active MEK (Fig. 2D). These findings indicate that MEK mediates epinephrine-induced mechanical hyperalgesia through a signaling pathway that is independent of PKA or PKC $\epsilon$.

In human embryonic kidney 293 (HEK293) cells transfected to overexpress $\beta_{2}$-adrenergic receptors, $\beta_{2}$ agonists activate ERKs through a signaling cascade that involves a $\mathrm{G}_{\mathrm{i} / \mathrm{o}}$-protein and Ras (Daaka et al., 1997; Della Rocca et al., 1997), whereas stimulation 


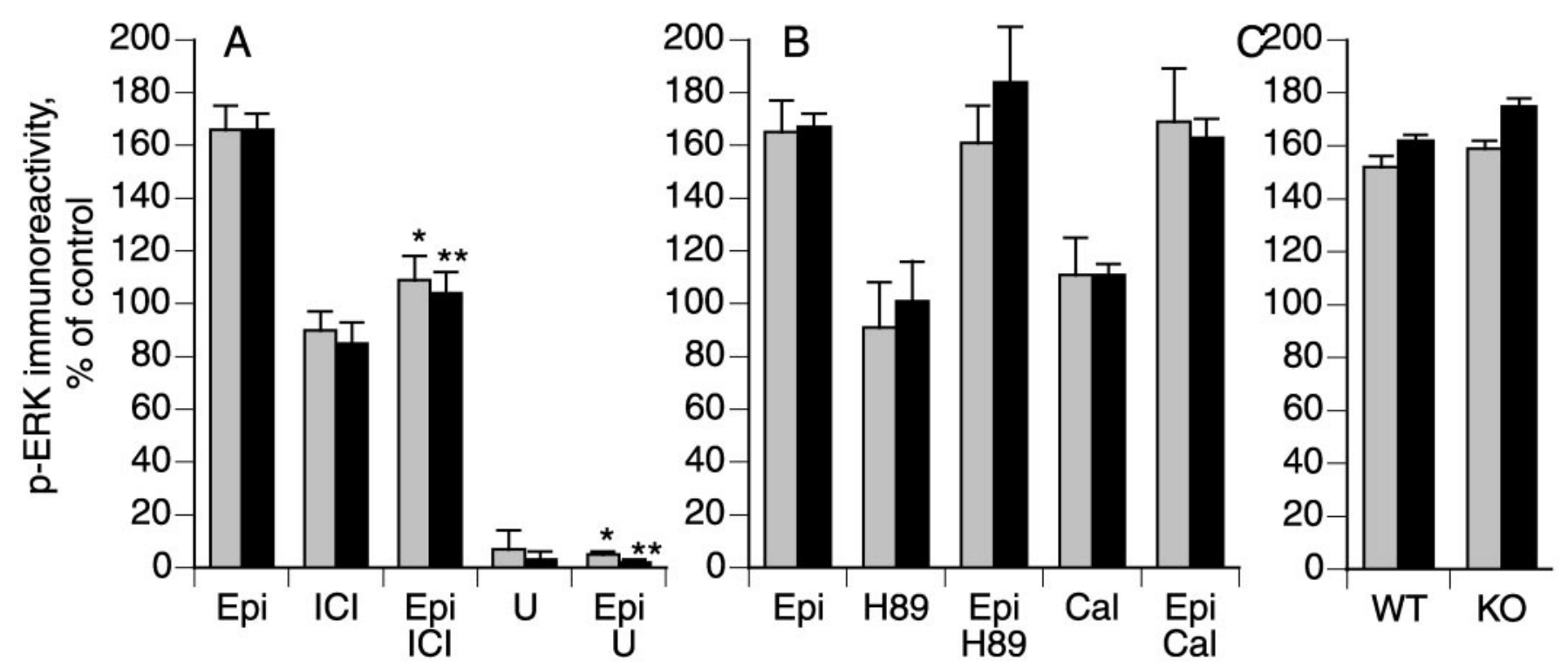

Figure 2. Epinephrine-induced phosphorylation of ERK1 (gray bars) and ERK2 (black bars) is reduced by inhibitors of $\beta_{2}$-adrenergic receptors and MEK and is independent of PKA and PKC $\epsilon$. $A$, DRG cultures were treated with $1 \mu \mathrm{M}$ epinephrine $(E p i ; n=9)$ for 5 min in the absence or presence of $(A)$ ICI $118,551(I C I ; 100 \mathrm{nM} ; n=7)$ or $\mathrm{U} 0126(U ; 10 \mu \mathrm{M} ; n=2)$. $B$, Cultures were treated with $1 \mu \mathrm{M}$ epinephrine $(E p i ; n=11)$ for 5 min in the absence or presence of H89 $(1 \mu \mathrm{M} ; n=5)$ or calphostin $\mathrm{C}(\mathrm{Cal} ; 1 \mu \mathrm{M} ; n=7)$. $C$, DRGs cultured from PKC $\epsilon$ wild-type $(W T)$ or knock-out $(K O)$ mice were treated with $1 \mu \mathrm{M}$ epinephrine for $5 \mathrm{~min}(n=3)$. Data are mean \pm SE values. ${ }^{*} p<0.05$ compared with phospho-ERK1 in epinephrine-treated cells; ${ }^{* *} p<0.05$ compared with phospho-ERK2 measured in epinephrine-treated cells (one-way ANOVA and Tukey's multiple comparison test).

of endogenous $\beta_{2}$ receptors activates ERKs through a pathway involving $\mathrm{G}_{\mathrm{s}}$ and Rap-1 (Schmitt and Stork, 2000). To examine pathways involved in $\beta_{2}$-mediated activation of ERKs in DRG neurons, we treated rat DRG cultures with pertussis toxin to inactivate $G_{i / o}$ and with the isoprenylation inhibitor perillic acid (Hardcastle et al., 1999). Both of these agents reduced epinephrine-mediated mechanical hyperalgesia (Fig. 4A,B). Small GTPases are generally modified post-translationally by the addition of the isoprenaloids farnesyl or geranylgeranyl to a cysteine residue near the C terminus (Zhang and Casey, 1996). Ras proteins are preferentially farnesylated, and inhibitors of farnesyltransferase block the transforming ability of H-Ras (Kohl et al., 1994). In contrast, Rap1A and B, which have a leucine residue at their $C$ termini, are preferentially geranylgeranylated. Treatment with FTase I, which inhibits Ras farnesylation, attenuated epinephrine-mediated mechanical hyperalgesia (Fig. 4C). Similarly, pertussis toxin and FTase I prevented epinephrineinduced phosphorylation of ERK1/2 (Fig. 5). These studies suggest that a $\mathrm{G}_{\mathrm{i} / \mathrm{o}}-\mathrm{Ras}-\mathrm{ERK} 1 / 2$ pathway contributes to epinephrine-induced hyperalgesia.

\section{DISCUSSION}

Second-messenger signaling pathways involving PKA and PKC $\epsilon$ have been implicated previously in nociceptor sensitization (Khasar et al., 1999a,b). This report provides the first demonstration of a role for ERK signaling in this process. Using kinaseselective inhibitors, we found that epinephrine-induced phosphorylation of ERK1/2 is independent of PKA and PKC $\epsilon$. In vivo, activated MEK was sufficient to cause a hyperalgesia that does not require PKA or PKC $\epsilon$. Conversely, PKC $\epsilon$ - and PKA ( $\left.\mathrm{PGE}_{2}\right)$ mediated hyperalgesia was independent of MEK activity. Therefore, ERKs, PKA, and PKC $\epsilon$ appear to define three independent signaling pathways that mediate nociceptor sensitization by inflammatory mediators.

$\beta_{2}$-adrenergic receptor activation stimulates ERK phosphory- lation in HEK293 cells (Daaka et al., 1997; Della Rocca et al., 1997; Schmitt and Stork, 2000), COS-7 cells (Maudsley et al., 2000), S49 lymphoma cells (Wan and Huang, 1998), and cardiac myocytes (Zou et al., 1999). Some of the most detailed studies have been performed with HEK293 cells in which endogenous $\beta_{2}$ receptors activate ERKs through a pathway involving $G_{s}$, PKA, Rap1, and B-Raf (Schmitt and Stork, 2000). It is unlikely that Rap1 plays a role in $\beta_{2}$ receptor-mediated nociceptor sensitization because treatment with the PKA inhibitor H89 did not block epinephrine-induced ERK phosphorylation or mechanical hyperalgesia. In HEK293 cells transfected to overexpress $\beta_{2}$ receptors, epinephrine stimulates a different pathway resulting in activation of $\mathrm{G}_{\mathrm{i} / \mathrm{o}}$ and Src, and transactivation of EGF receptors leading to stimulation of Ras, MEK, and ERKs (Daaka et al., 1997; Della Rocca et al., 1997; Maudsley et al., 2000). We found evidence to support involvement of $\mathrm{G}_{\mathrm{i} / \mathrm{o}}$ and Ras in $\beta_{2}$ receptor-mediated ERK activation in DRG neurons and hyperalgesia.

In addition to regulating gene expression, cell proliferation, differentiation, development, and apoptosis (Lewis et al., 1998), ERKs have been implicated in neural plasticity associated with learning and memory (Bailey et al., 1997; Martin et al., 1997). Here we demonstrate a role for ERK signaling in another form of neural plasticity, namely sensitization of nociceptors. The downstream effectors of ERKs that mediate nociceptor sensitization are not known. Because modulation of voltage-sensitive potassium channels may contribute to nociceptor sensitization (Evans et al., 1999), recent findings that the A-type $\mathrm{K}^{+}$channel Kv4.2 is a substrate for ERK1/2 (Adams et al., 2000) may provide such a downstream target. Production of arachidonic acid metabolites by cytoplasmic phospholipase $\mathrm{A}_{2}$, another substrate of ERK1/2 (Lin et al., 1993), has been implicated in signaling pathways involved in nociceptor function (Hwang et al., 2000; Piomelli, 2001). Thus, at least two known ERK1/2 substrates are potential mediators of nociceptor sensitization induced by ERK signaling. 

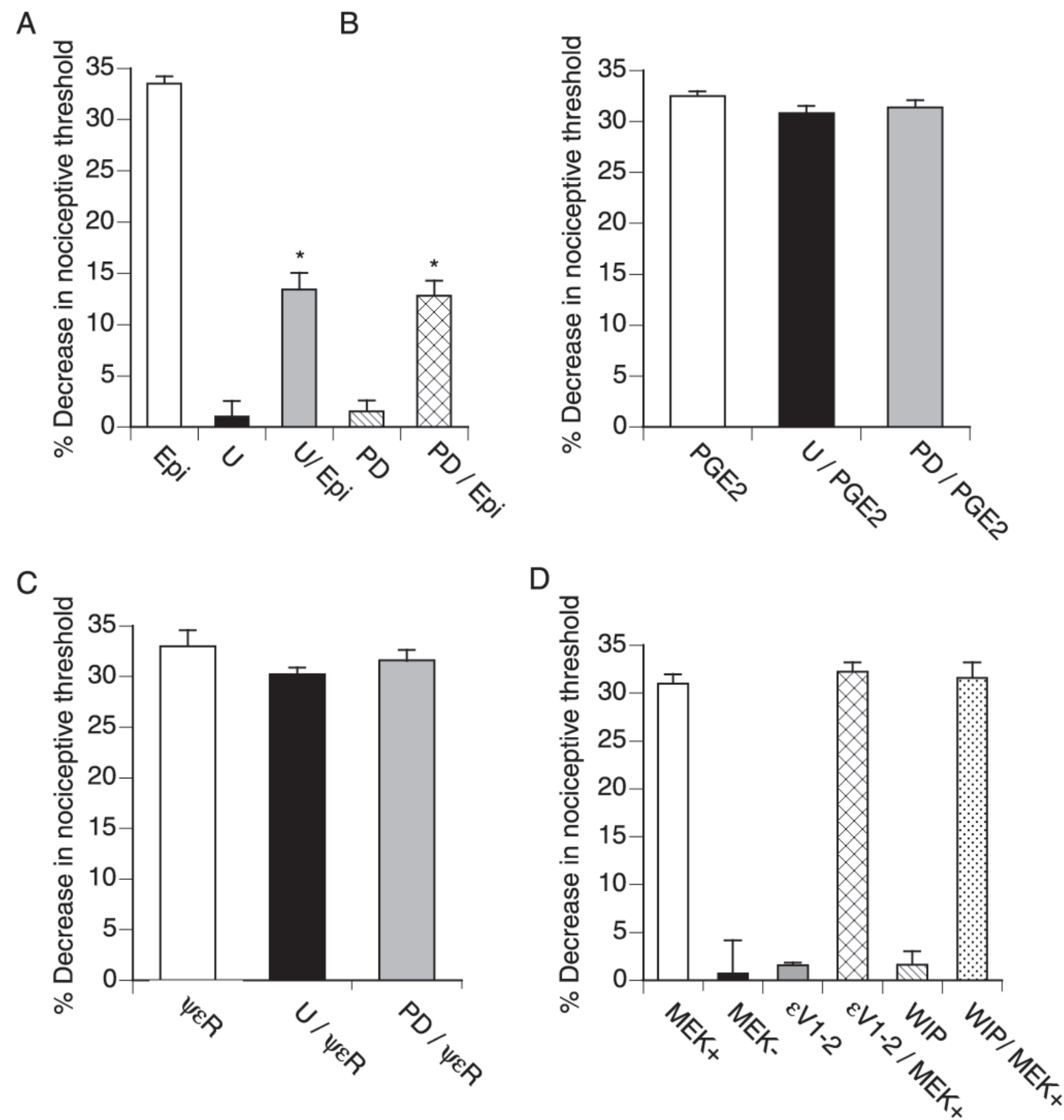

Figure 3. Epinephrine-induced hyperalgesia is mediated by MEK, independent of PKA and PKC $\epsilon$. The mean \pm SE baseline threshold before drug administration was $108.0 \pm 0.5 \mathrm{gm}(n=162)$. A, Rats were treated intradermally with epinephrine $(E p i ; 100 \mathrm{ng} ; n=12), \mathrm{UO} 126(U ; 1 \mu \mathrm{g} ; n=6)$, UO126 plus epinephrine (U/Epi; $n=12)$, PD98059 (PD; $1 \mu \mathrm{g} ; n=6)$, and PD98059 plus epinephrine $(P D / E p i ; n=12)$. B, Rats were treated intradermally with $\mathrm{PGE}_{2}(100 \mathrm{ng} ; n=6)$, UO126 plus $\mathrm{PGE}_{2}\left(U / P G E_{2} ; n=6\right)$, and PD98059 plus $\mathrm{PGE}_{2}\left(P D / P G E_{2} ; n=6\right)$. $C$, Rats were treated intradermally with the PKC $\epsilon$ agonist $\psi \epsilon \mathrm{RACK}(\psi \epsilon R ; 1 \mu \mathrm{g} ; n=6)$, UO126 plus PKC $\epsilon$ agonist $(U / \psi \epsilon R ; n=6)$, and PD98059 plus PKC $\epsilon$ agonist $(P D / \psi \epsilon R ; n=6)$. D, Rats were treated intradermally with active MEK (MEK+; $0.5 \mathrm{U} ; n=12)$, inactive MEK $(M E K-; 1 \mu \mathrm{g} ; n=6)$, PKC $\epsilon$ inhibitor $(\epsilon V 1-2 ; 1 \mu \mathrm{g} ; n=6)$, PKC $\epsilon$ inhibitor plus active MEK $(\epsilon V 1-2 / M E K+; n=6)$, WIPTIDE $(W I P ; 1 \mu \mathrm{g} ; n=6)$, and WIPTIDE plus active MEK $(W I P / M E K+; n=6)$. ${ }^{*} p<0.05$ by one-way ANOVA and Newman-Keuls test.

Activation of ERKs by $\beta$-adrenergic receptor stimulation may contribute to inflammatory pain, because increased levels of epinephrine are found at sites of inflammation (Mikhailov and Rusanova, 1993) and $\beta$-adrenergic receptor antagonists reduce inflammatory hyperalgesia (Cunha et al., 1991). Catecholamines released from sympathetic nerve terminals and from the adrenal medulla also appear to contribute to sympathetically maintained pain and stress-aggravated pain (Choi and Rowbotham, 1997; 

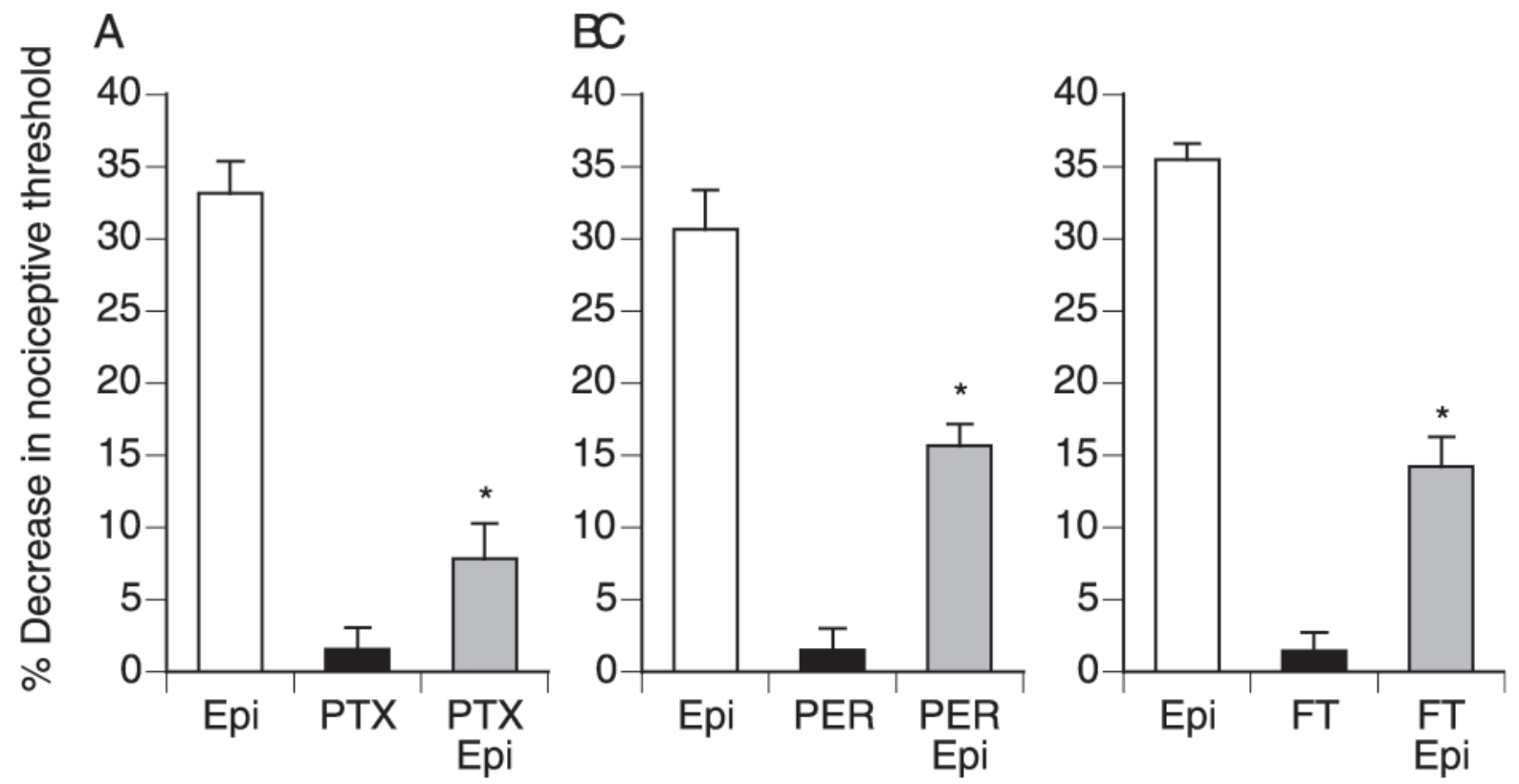

Figure 4. Epinephrine-induced mechanical hyperalgesia is mediated by a $\mathrm{G}_{\mathrm{i} / \mathrm{o}}$-protein and Ras. The mean $\pm \mathrm{SE}$ baseline threshold before drug administration was $108.0 \pm 0.5 \mathrm{gm}(n=162)$. A, Rats were treated intradermally with epinephrine (Epi; $100 \mathrm{ng} ; n=12)$, pertussis toxin $(P T X ; 1 \mu \mathrm{g}$; $n=6)$, or pertussis toxin plus epinephrine $(P T X / E p i ; n=8)$. B, Rats were treated intradermally with epinephrine $(E p i ; 100 \mathrm{ng} ; n=12)$, perillic acid $(P E R ; 1 \mu \mathrm{g} ; n=6)$, or perillic acid plus epinephrine $(P E R / E p i ; n=8) . C$, Rats were treated intradermally with epinephrine $(E p i ; 100 \mathrm{ng} ; n=12)$, farnesyltransferase inhibitor I $(F T ; 1 \mu \mathrm{g} ; n=6)$, or farnesyltransferase inhibitor I plus epinephrine $(F T / E p i ; n=8)$. * $p<0.05$ by one-way ANOVA and Newman-Keuls test.

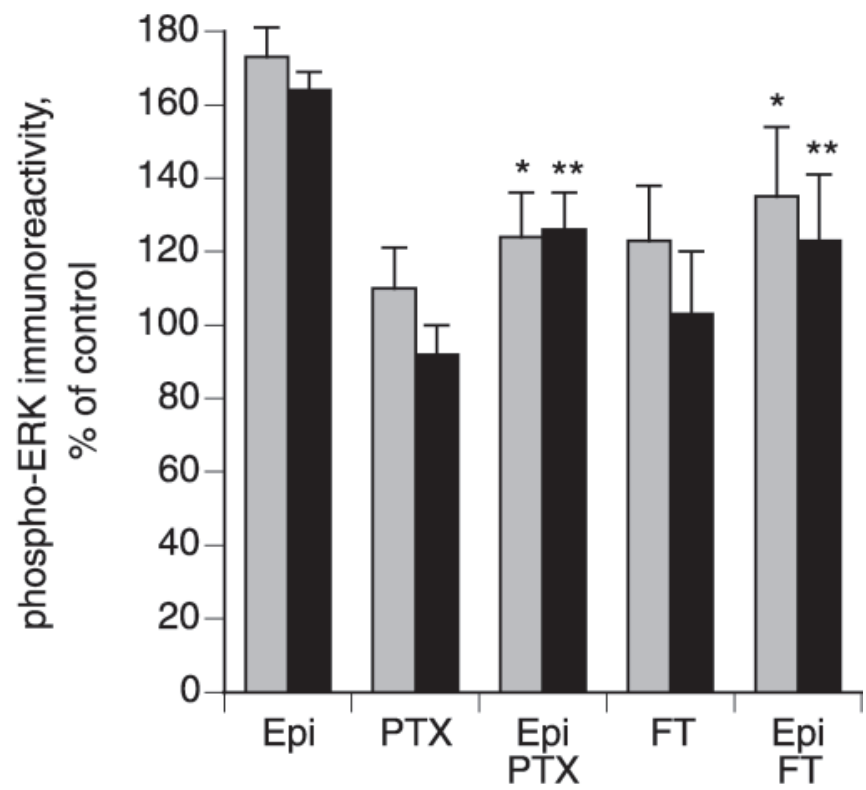

Figure 5. Pertussis toxin $(P T X)$ and farnesyltransferase inhibitor I $(F T)$ inhibit epinephrine-induced ERK1/2 phosphorylation in DRG cultures. DRG cultures were treated with $100 \mathrm{~nm}$ pertussis toxin or $1 \mu \mathrm{M}$ FTase I for $16 \mathrm{hr}$ and then with or without $1 \mu \mathrm{M}$ epinephrine (Epi) as indicated. Data are mean \pm SE values from five to eight experiments. * $p<0.05$ compared with phospho-ERK1 in epinephrine-treated cells; * $p<0.05$ compared with phospho-ERK2 measured in epinephrine-treated cells (one-way ANOVA and Newman-Keuls test).

Khasar et al., 1998b). When injected intradermally, epinephrine lowers the nociceptive threshold with an $\mathrm{ED}_{50}$ of $\sim 20 \mathrm{ng}$ (Khasar et al., 1999b), which is similar to the $\mathrm{ED}_{50}$ for bradykinin and $\mathrm{PGE}_{2}$ (Khasar et al., 1993). In addition to catecholamines, NGF
(Safieh-Garabedian et al., 1997) and bradykinin (Levine and Taiwo, 1994) are two other hyperalgesic mediators released during inflammation and tissue damage that can activate ERK1/2 (Clark and Murray, 1995; Hundle et al., 1995). This suggests that ERK signaling plays an important role in pain states evoked by several different mediators and pathological conditions. ERK pathways have several components, affording an opportunity for antagonism at many levels. Therefore, inhibition of ERK signaling in nociceptors may provide a fruitful strategy for the discovery of novel analgesics.

\section{REFERENCES}

Adams JP, Anderson AE, Varga AW, Dineley KT, Cook RG, Pfaffinger PJ, Sweatt JD (2000) The A-type potassium channel Kv4.2 is a substrate for the mitogen-activated protein kinase ERK. J Neurochem 75:2277-2287.

Aley KO, Levine JD (1999) Role of protein kinase A in the maintenance of inflammatory pain. J Neurosci 19:2181-2186.

Aley KO, McCarter G, Levine JD (1998) Nitric oxide signaling in pain and nociceptor sensitization in the rat. J Neurosci 18:7008-7014.

Aley KO, Messing RO, Mochly-Rosen D, Levine JD (2000) Chronic hypersensitivity for inflammatory nociceptor sensitization mediated by the epsilon isozyme of protein kinase C. J Neurosci 20:4680-4685.

Bailey CH, Kaang B-K, Chen M, Martin KC, Lim C-S, Casadio A, Kandel ER (1997) Mutation in the phosphorylation sites of MAP kinase blocks learning-related internalization of apCAM in Aplysia sensory neurons. Neuron 18:913-924.

Brodie C, Bogi K, Acs P, Lazarovici P, Petrovics G, Anderson WB, Blumberg PM (1999) Protein kinase C-epsilon plays a role in neurite outgrowth in response to epidermal growth factor and nerve growth factor in PC12 cells. Cell Growth Differ 10:183-191.

Cesare P, Dekker LV, Sardini A, Parker PJ, McNaughton PA (1999) Specific involvement of PKC-epsilon in sensitization of the neuronal response to painful heat. Neuron 23:617-624.

Chen X, Levine JD (1999) NOS inhibitor antagonism of PGE2-induced mechanical sensitization of cutaneous $\mathrm{C}$-fiber nociceptors in the rat. J Neurophysiol 81:963-966.

Chijiwa T, Mishima A, Hagiwara M, Sano M, Hayashi K, Inoue T, Naito K, Toshioka T, Hidaka H (1990) Inhibition of forskolin-induced neurite outgrowth and protein phosphorylation by a newly synthesized selective inhibitor of cyclic AMP-dependent protein kinase, $N-[2-(p-$ 
bromocinnamylamino)ethyl]-5-isoquinolinesulfonamide (H-89), of PC12D pheochromocytoma cells. J Biol Chem 265:5267-5272.

Choi B, Rowbotham MC (1997) Effect of adrenergic receptor activation on post-herpetic neuralgia pain and sensory disturbances. Pain 69:55-63.

Clark KJ, Murray AW (1995) Evidence that the bradykinin-induced activation of phospholipase $\mathrm{D}$ and of the mitogen-activated protein kinase cascade involve different protein kinase $\mathrm{C}$ isoforms. J Biol Chem 270:7097-7103.

Cunha FQ, Lorenzetti BB, Poole S, Ferreira SH (1991) Interleukin-8 as a mediator of sympathetic pain. Br J Pharmacol 104:765-767.

Daaka Y, Luttrell LM, Lefkowitz RJ (1997) Switching of the coupling of the $\beta_{2}$-adrenergic receptor to different $\mathrm{G}$ proteins by protein kinase A. Nature 390:88-91.

Della Rocca GJ, van Biesen T, Daaka Y, Luttrell DK, Luttrell LM, Lefkowitz RJ (1997) Ras-dependent mitogen-activated protein kinase activation by $\mathrm{G}$ protein-coupled receptors. $\mathrm{J}$ Biol Chem 272:19125-19132.

Dorn II GW, Souroujon MC, Liron T, Chen CH, Gray MO, Zhou HZ, Csukai M, Wu G, Lorenz JN, Mochly-Rosen D (1999) Sustained in vivo cardiac protection by a rationally designed peptide that causes epsilon protein kinase $C$ translocation. Proc Natl Acad Sci USA 96:12798-12803.

Evans AR, Vasko MR, Nicol GD (1999) The cAMP transduction cascade mediates the PGE2-induced inhibition of potassium currents in rat sensory neurones. J Physiol (Lond) 516:163-178.

Favata MF, Horiuchi KY, Manos EJ, Daulerio AJ, Stradley DA, Feeser WS, Van Dyk DE, Pitts WJ, Earl RA, Hobbs F, Copeland RA, Magolda RL, Scherle PA, Trzaskos JM (1998) Identification of a novel inhibitor of mitogen-activated protein kinase kinase. J Biol Chem 273:18623-18632.

Gold MS, Reichling DB, Shuster MJ, Levine JD (1996) Hyperalgesic agents increase a tetrodotoxin-resistant $\mathrm{Na}^{+}$current in nociceptors. Proc Natl Acad Sci USA 93:1108-1112.

Gold MS, Levine JD, Correa AM (1998) Modulation of TTX-R INa by PKC and PKA and their role in PGE2-induced sensitization of rat sensory neurons in vitro. J Neurosci 18:10345-10355.

Grewal SS, Horgan AM, York RD, Withers GS, Banker GA, Stork PJS (2000) Neuronal calcium activates a Rap1 and B-Raf signaling pathway via the cyclic adenosine monophosphate-dependent protein-kinase. J Biol Chem 275:3722-3728.

Hardcastle IR, Rowlands MG, Barber AM, Grimshaw RM, Mohan MK, Nutley BP, Jarman M (1999) Inhibition of protein prenylation by metabolites of limonene. Biochem Pharmacol 57:801-809.

Hundle B, McMahon T, Dadgar J, Messing RO (1995) Overexpression of $\epsilon$-protein kinase $\mathrm{C}$ enhances nerve growth factor-induced phosphorylation of mitogen-activated protein kinases and neurite outgrowth. J Biol Chem 270:30134-30140.

Hundle B, McMahon T, Dadgar J, Chen C-H, Mochly-Rosen D, Messing RO (1997) An inhibitory fragment derived from protein kinase C $\epsilon$ prevents enhancement of nerve growth factor responses by ethanol and phorbol esters. J Biol Chem 272:15028-15035.

Hwang SW, Cho H, Kwak J, Lee SY, Kang CJ, Jung J, Cho S, Min KH, Suh YG, Kim D, Oh U (2000) Direct activation of capsaicin receptors by products of lipoxygenases: endogenous capsaicin-like substances. Proc Natl Acad Sci USA 97:6155-6160.

Johnson JA, Gray MO, Chen C-H, Mochly-Rosen D (1996) A protein kinase $\mathrm{C}$ translocation inhibitor as an isozyme-selective antagonist of cardiac function. J Biol Chem 271:24962-24966.

Kawasaki H, Springett GM, Mochizuki N, Toki S, Nakaya M, Matsuda M, Housman DE, Graybiel AM (1998) A family of cAMP-binding proteins that directly activate Rap1. Science 282:2275-2279.

Khasar SG, Green PG, Levine JD (1993) Comparison of intradermal and subcutaneous hyperalgesic effects of inflammatory mediators in the rat. Neurosci Lett 153:215-218.

Khasar SG, Wang JF, Taiwo YO, Heller PH, Green PG, Levine JD (1995) Mu-opioid agonist enhancement of prostaglandin-induced hyperalgesia in the rat: a G-protein beta gamma subunit-mediated effect? Neuroscience 67:189-195.

Khasar SG, Gold MS, Levine JD (1998a) A tetrodotoxin-resistant sodium current mediates inflammatory pain in the rat. Neurosci Lett 256:17-20.

Khasar SG, Miao FJ, Jänig W, Levine JD (1998b) Vagotomy-induced enhancement of mechanical hyperalgesia in the rat is sympathoadrenalmediated. J Neurosci 18:3043-3049.

Khasar SG, Lin Y-H, Martin A, Dadgar J, McMahon T, Wang D, Hundle B, Aley KO, Isenberg W, McCarter G, Green PG, Hodge CW, Levine
JD, Messing RO (1999a) A novel nociceptor signaling pathway revealed in protein kinase $C \epsilon$ mutant mice. Neuron 24:253-260.

Khasar SG, McCarter G, Levine JD (1999b) Epinephrine produces a beta-adrenergic receptor-mediated mechanical hyperalgesia and in vitro sensitization of rat nociceptors. J Neurophysiol 81:1104-1112.

Kohl NE, Wilson FR, Mosser SD, Giuliani E, DeSolms SJ, Conner MW, Anthony NJ, Holtz WJ, Gomez RP, Lee T-J, Smith RL, Graham SL, Hartman GD, Gibbs JB, Oliff A (1994) Protein farnesyltransferase inhibitors block the growth of ras-dependent tumors in nude mice. Proc Natl Acad Sci USA 91:9141-9145.

Levine JD, Taiwo Y (1994) Inflammatory pain. In: Textbook of pain (Wall PD, Melzack R, eds), pp 45-56. Edinburgh: Churchill Livingstone.

Lewis TS, Shapiro PS, Ahn NG (1998) Signal transduction through MAP kinase cascades. Adv Cancer Res 74:49-139.

Lin L-L, Wartmann M, Lin AY, Knopf JL, Seth A, Davis RJ (1993) cPLA $_{2}$ is phosphorylated and activated by MAP kinase. Cell $72: 269-278$

Martin KC, Michael D, Rose JC, Barad M, Casadio A, Zhu H, Kandel ER (1997) MAP kinase translocates into the nucleus of the presynaptic cell and is required for long-term facilitation in Aplysia. Neuron 18:899-912.

Maudsley S, Pierce KL, Zamah AM, Miller WE, Ahn S, Daaka Y, Lefkowitz RJ, Luttrell LM (2000) The $\beta_{2}$-adrenergic receptor mediates extracellular signal-regulated kinase activation via assembly of a multi-receptor complex with the epidermal growth factor receptor. J Biol Chem 275:9572-9580.

Mayne GC, Murray AW (1998) Evidence that protein kinase Cepsilon mediates phorbol ester inhibition of calphostin $\mathrm{C}$ - and tumor necrosis factor-alpha-induced apoptosis in U937 histiocytic lymphoma cells. J Biol Chem 273:24115-24121.

Mikhailov VV, Rusanova AG (1993) The interrelationship of the catecholamine and protein content of the tissue of the subman-dibular salivary glands and the mucosa during the secretory cycle in chronic inflammation of the oral soft tissues. Biull Eksp Biol Med 116:472-474

Ohtsuka T, Shimizu K, Yamamori B, Kuroda S, Takai Y (1996) Activation of brain B-Raf protein kinase by Rap1B small GTP-binding protein. J Biol Chem 271:1258-1261.

Piomelli D (2001) The ligand that came from within. Trends Pharmacol Sci 22:17-19.

Safieh-Garabedian B, Kanaan SA, Haddad JJ, Jaoude PA, Jabbur SJ, Saade NE (1997) Involvement of interleukin-1 beta, nerve growth factor and prostaglandin E2 in endotoxin-induced localized inflammatory hyperalgesia. Br J Pharmacol 121:1619-1626.

Samama P, Pei G, Costa T, Cotecchia S, Lefkowitz RJ (1994) Negative antagonists promote an inactive conformation of the beta 2 -adrenergic receptor. Mol Pharmacol 45:390-394

Schmitt JM, Stork PJS (2000) $\beta_{2}$-adrenergic receptor activates extracellular signal-regulated kinases (ERKs) via the small G protein Rap1 and the serine/threonine kinase B-Raf. J Biol Chem 275:25342-25350.

Taiwo YO, Levine JD (1989) Contribution of guanine nucleotide regulatory proteins to prostaglandin hyperalgesia in the rat. Brain Res 492:400-403.

Tsapis A, Kepes A (1977) Transient breakdown of the permeability barrier of the membrane of Escherichia coli upon hypoosmotic shock. Biochim Biophys Acta 469:1-12.

Vossler MR, Yao H, York RD, Pan M-G, Rim CS, Stork PJS (1997) cAMP activates MAP kinase and Elk-1 through a B-Raf- and Rap1dependent pathway. Cell 89:73-82.

Wan Y, Huang X-Y (1998) Analysis of the $\mathrm{G}_{\mathrm{s}} /$ mitogen-activated protein kinase pathway in mutant S49 cells. J Biol Chem 273:14533-14537.

West LK, Huang L (1980) Transient permeabilization induced osmotically in membrane vesicles from Torpedo electroplax: a mild procedure for trapping small molecules. Biochemistry 19:4418-4423.

Widdicombe JH, Azizi F, Kang T, Pittet JF (1996) Transient permeabilization of airway epithelium by mucosal water. J Appl Physiol 81:491499.

York RD, Yao H, Dillon T, Ellig CL, Eckert SP, McCleskey EW, Stork PJS (1998) Rap1 mediates sustained MAP kinase activation induced by nerve growth factor. Nature 392:622-626.

Zhang FL, Casey PJ (1996) Protein prenylation: molecular mechanisms and functional consequences. Annu Rev Biochem 65:241-269.

Zou Y, Komuro I, Yamazaki T, Kudoh S, Uozumi H, Kadowaki T, Yazaki Y (1999) Both Gs and Gi proteins are critically involved in isoproterenol-induced cardiomyocyte hypertrophy. J Biol Chem 274: $9760-9770$ 